\title{
Transformations of the "Syrian" Literary Field Since 2011
}

\section{Felix Lang}

The intellectual and artistic space in which Syrian authors, filmmakers, and artists move has changed markedly over the last eight years. In the light of the events unfolding in Syria since spring 2011, we are quick to attribute these changes to the revolution and the ensuing armed conflicts. Indeed, political crises as "turning points" have always held an important narratological function in literary history, as they have in any other fields which are in a dominated position in relation to the political sphere ${ }^{1}$. The discursive consolidation of such turning points and points of rupture tends to blur relations of causality by collectively attributing changes to "The War". Continuities, which are grounded in the specific history and structure of the field, tend to be obscured by the dominant narratives of rupture and change.

One way of counterchecking the powerful narratives of change current in academia and the media, as well as in the literary field itself, lies in a quantitative approach little used in studies of Arab cultural production so far. Thus, in the present chapter, I will present some preliminary findings based on the data collected for a database on Syrian literature that is currently being assembled at the Department of Arabic Literature and Culture at the University of Marburg ${ }^{2}$. The database stores bibliographic data on the published works of 210 Syrian writers who

I would like to thank our student assistants Hannah El-Hitami, Jan Pfeiffer and Wael Alokla who helped to compile the data analysed in this chapter.

\section{F. Lang $(\bowtie)$}

Centrum für Nah- und Mittelost Studien, Philipps-Universität Marburg, Marburg, Germany

e-mail: felix.lang@staff.uni-marburg.de 
have published at least one novel between 1980 and 2016. This includes nearly every living Syrian novelist in 2016. In addition to approximately 2500 novels, the database contains over 5000 reviews, articles, publications about and by these authors and their literary works.

This chapter considers changes in the field between 2005 and 2016 insomuch as they can be inferred from the data collected. It intends to critically evaluate the widespread assumption that the uprising constitutes a watershed moment in Syrian cultural production (e.g. Chiti 2016; Cooke 2016; Wedeen 2013; Ziter 2015). While much of this work has been dedicated to themes and forms of art and literature produced in the wake of the revolution, few scholars have considered structural changes ${ }^{3}$. In the following, the data available will be used to elucidate the question whether, and if so in which ways, the events that have been unfolding since 2011 have had a demonstrable effect on various important features of the field.

\section{The Field}

As Mohja Kahf has pointed out, in a familiar move of criticizing a notion of national literatures transposed on the Arab World by Western academia, there is no such thing as Syrian literature (Kahf 2001). The literary language shared across more than 20 nation-states is the foundation of what is in many ways a transnational space of literary production, which stretches to its limits an orthodox, nation-centered approach to the literary field. Historically, we have seen close connections between Syria's intellectual elite and the state. For the Baath party, which first came to power in 1963, intellectuals and writers had an important political role to play. Consequently, many institutions of the field were controlled by the state: many artists and intellectuals depended-and still depend — on the state for employment. ${ }^{4}$ Two of the most important Syrian publishers of the last 40 years are the Ministry of Culture (Manshürāt Wizärat al-thaqāfa) and the publishing house of the state-controlled Arab Union of Writers (Ittih̄äd al-kuttāb al-'arab). However, almost the same number of novels written by Syrians were published in Beirut as in all Syria during the period in question. Likewise, institutions of consecration are not found in Syria aloneindeed, the regional and international institutions' recognition is often connected with higher symbolic capital. Pan-Arab newspapers, notably al-Hayāt with its literary supplement, along with newspapers based in other states of the region, such as Lebanon's al-Akhbār, are important sources of symbolic capital for Syrian authors. Whereas the relative value of such reviews is difficult to determine 
based on quantitative data, the sheer number of reviews in these media vouches for the relevance of such international actors: thus, al-Hayāt and the Al-Jazeera website rank highest when it comes to publications about writers from our corpus. Regional literary awards also carry ample weight: the International Prize for Arabic Fiction is the prime example.

The integration of Syrian writers within the wider Arab field of cultural production also makes it difficult to speak of an essentially Syrian literature on the level of symbolic products. Kahf, in her article quoted above, makes a case for the "silences" and circumvention of censorship laws and other forms of control required from writers in an authoritarian system as a unifying characteristic of Syrian literature, however she acknowledges that authors in Iraq and Libya faced similar conditions for much of the second half of the twentieth century. It is conceivable that the literary production turning around the 2011 uprising and the ongoing war in Syria may come to be seen as the beginning of a truly Syrian literary tradition-analogous to the civil war novels in 1980s and 1990s Lebanon or the trauma of occupation and exile that draws together Palestinian literature. However, to this point these texts remain essentially transnational through their reference to notions of trauma, testimony and documentation.

Traditionally, as in many parts of the Arab World, poetry has been the most prestigious genre of literary production. This dominance has been seen to be waning since at least the 1990s (see Jacquemond 2003, p. 229). In the aftermath of 2011, and in the international segment of the field, poetry played a minor role as a form of artistic expression: the dominant voices in the field now belong to a younger generation of novelists. Few, if any, of those who have recently left their mark on the field are poets. The short story, which has also been a more important literary genre in the Arab world than in the West, retains much of its importance in a context where online platforms, magazines, and social media have acquired an important role in the publication of literary works. ${ }^{5}$

While there may be no Syrian literature, there are undoubtedly novelists, poets, and short story writers who were born in Syria. Currently, at least three loosely defined generations of Syrian writers can be discerned. Authors who had already begun their literary careers before the Baath Party came to power in Syria in 1963 form the most highly consecrated generation. These authors inlcude the poet Adonis, who left Syria in 1955 and later renounced Syrian citizenship, and the novelists Hanna Mina (Ḥannā Mīna), Ulfat Idlibi (Ulfat Al-Idlibī), and Walid Ikhlasi (Walīd Ikhlāșī). The next generation comprises authors who made their debuts in the 1980s, when younger writers such as Salim Barakat (Salīm Barakāt) were challenging the social realism of Mina and Ikhlasi. Finally, the late 1990s and early 2000s saw the entry to the field of a group of writers who have since 
become the dominant voices in the international segment of the field during the conflict in Syria. Samar Yazbek (Samar Yazbik) published her first collection of short stories in 1999 (Yazbik 1999), Rosa Yassin Hassan (Rūzā Yāsīn Ḥasan) in 2000, and Khaled Khalifa's (Khalid Khalīfa) first novel (Khalīfa 2000) was also released in 2000.

In structural terms, the most notable effect of the violent conflict in Syria on the literary field no doubt arises from the displacement of a considerable part of its players. Most of Syria's well-known authors, as well as a host of younger writers in the early stages of their careers, have left Syria since 2011. Typically, writers, as well as other artists, first moved to neighboring countries, especially Lebanon and Turkey, and later settled in Europe, with Germany as one of the most important destinations. Berlin soon became a center of the Syrian arts scene.

This displacement entailed the inclusion of a completely new range of international actors that have not been previously part of the field: public diplomacy organizations and their various funding programs, foreign publishers and translators, but also new platforms for publication such as online magazines like Dahnon, Al-Jumhuriya and Raseef 22.

Arguably, these two intertwined processes drive the transformation of the Syrian literary field. In the following, the data gathered will be used to two ends. First, bibliographical data will be used to describe more precisely the process of internationalization. Second, I seek to gauge how the inclusion of new intermediaries, along with the changing involvement of established intermediaries, is bound to change the structure and the hierarchies of the field.

\section{Trends of Internationalization}

\section{Publishers}

First, we will consider the development of the overall number of publications and the countries where Syrian authors have been published. These developments are charted based on the full set of novels published between 2005 and 2015 (Fig. 1).

The first thing to be noted in this chart is that the overall number of titles produced by Syrian authors has not been affected by the conflict beginning in 2011 - in fact, the mean output of about 48 titles per year is the same for the period from 2005 to 2010 as for the time period from 2011 to 2015. Nonetheless, we find two discernible peaks in literary production: one in 2008, which is most likely connected to the surge of publications in the context of the Damascus Arab Capital for Culture celebrations that year. The second, in 2014, might be attributed to a surge in publications connected to the war. More significantly, we see 


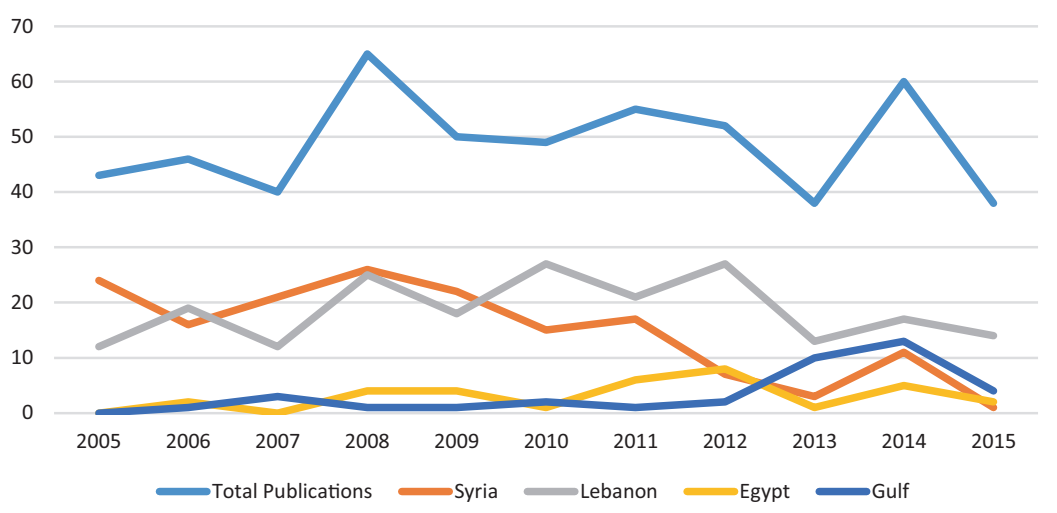

Fig. 1 Publications by Country (database of the research group "Figures of Thought I Turning Points. Cultural Practices and Social Change in the Arab World" (DFG) at CNMS, Marburg)

a steady decline of literary production from 2011 to 2013, until it picks up again the following year. This slump would seem to be connected to the outbreak of the conflict in Syria. The number of works published by Syrian publishers shrunk by a staggering $80 \%$ in these two years while overall production only decreased by $30 \%$. In the years between 2005 and 2010, approximately $40 \%$ of titles were published in Syria; in the years following the uprising, the proportion dropped to $15 \%$.

In other words, we see a clear trend towards internationalization of publishing, which appears to be a common feature of Arab literary fields in moments of crisis. Tristan Leperlier, in his work on the Algerian field during the Black Decade in the 1990s, finds similar dynamics at work: a growing number of publications in France (Leperlier 2019) compensates for the decrease of publishing in Algeria. In the Syrian case, the destinations of authors who publish abroad are more diverse, and clear trends are more difficult to identify. Lebanon's share, for instance, remains relatively stable between 37 and $39 \%$ of overall production. Egypt's publishing industry clearly plays a more important role for Syrian authors following 2011 , but it does so on a relatively small scale, with a proportion of about $10 \%$ of total production. The clearest trend, however, is the increasing importance of the publishing industry of Saudi Arabia and the Gulf states after 2011. In 2013 and 2014, publishers in the Gulf were the second most important group in the Syrian literary field after the regionally dominant Lebanese publishing houses. Reasons 
for this sudden growth might be found in the close connections that many Syrians had with the Gulf as a place of work ${ }^{6}$. At the same time, the publishing sector in the Gulf has been growing for a number of years, and finally, the Gulf countries' position in the regional conflict could also make the publication of Syrian authors critical of the regime a politically opportune endeavor.

\section{Translations}

Translations are another important marker of internationalization and recognition of Syrian authors abroad. Syrian authors, as well as authors writing in Arabic quite generally, are rarely translated into foreign languages, a fact that has been deplored by scholars of Arabic literature for decades ${ }^{7}$. Figure 2 shows the number of translations of works by the authors of the corpus, which were released by European and US publishers between 2005 and 2014. Numbers include translated texts in edited collections.

As we can see, the number of translations increased markedly from an average of four per year between 2006 and 2010 to an average of nine titles from 2011 to 2014. Translations of Adonis's works, which account for roughly a third of total translations, have been left out. Given the very low number of translations, the margin of error in these calculations is relatively high. However, it can be stated that the conflict in Syria has led to an increased interest in Syrian literature

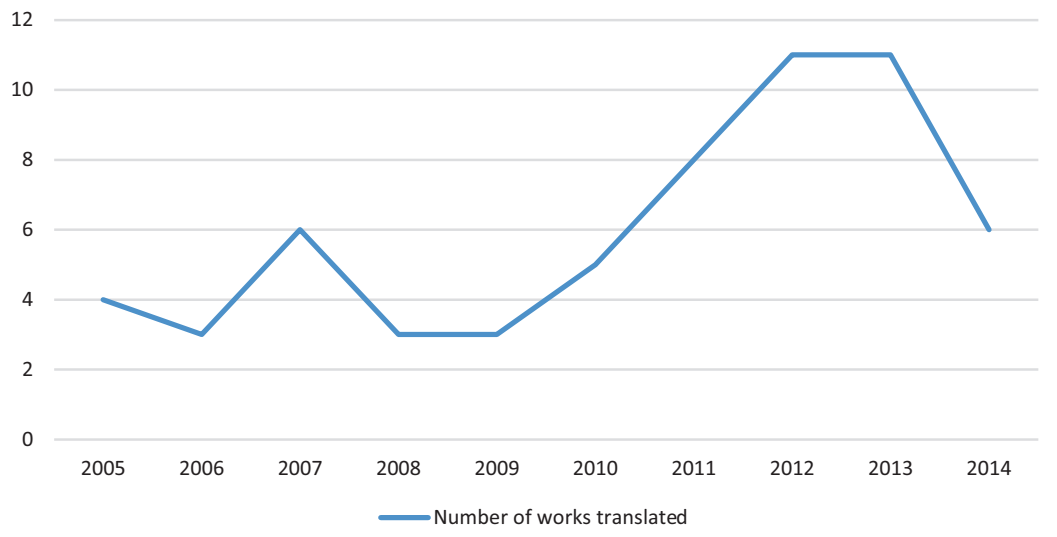

Fig. 2 Translations 
abroad. Before 2011, the target languages were almost exclusively French, English and German, whereas translations published after the outbreak of the conflict also included Spanish as well as smaller European languages such as Dutch and Swedish. The proportion of women writers remained unchanged at about $30 \%$ of the titles translated.

However, the increase in the number of translations should not be equated with the emergence of a readership for Syrian writers in general. The works of Samar Yazbek, particularly her diaries of the civil war, and Khaled Khalifa (primarily his novel In Praise of Hatred) account for over $40 \%$ of the translations between 2011 and 2014. Thus, while the number of published translations has almost doubled, the number of translated authors has increased only by two from 12 to 14. In addition, the vast majority of writers translated after 2011 had already been translated. The conflict mostly worked to firmly establish some of the younger authors, among them Yazbek and Khalifa, but also Rosa Yassin Hassan and (possibly) Dima Wannous (Dīma Wannūs) at the international pole of the Syrian field, while some older writers, such as Salim Barakat, Nihad Siris (Nihād Sīrīs) or the poet Faraj Bairaqdar (Faraj Bayraqdār) retain a certain international visibility.

As the well-established intermediaries in the literary field, publishers and translators connect the writer, the text, and the readership. As we have seen, for many Syrian authors Syrian publishers have been replaced by enterprises in other countries in the region, and Euro-American publishers and translators have concentrated on a small number of authors. In both cases, these developments pose a potential challenge to the established hierarchies in the field: the priorities of these new actors can present an advantage for writers who only enjoyed limited recognition before, provided their work fits the agenda of the new gatekeepers. Samar Yazbek, for instance, obviously managed to respond to a demand from European - and to some extent Syrian-readers with her diaries of a revolution, which more highly consecrated authors were unable to satisfy.

\section{Challenges to the Hierarchies of the Field}

Different publishers and translators are not the only intermediaries we encounter in authors' post-2011 professional trajectories. In the following, I consider reception in Arab and US/European media, as well as social media. For the compilation of this data, we have concentrated on a sample of 60 authors divided in five age groups, with 2016 being the year of reference. The proportion of male to female authors was made to reflect the distribution between the sexes in the 
larger group of 210 authors referred to above. In order to reflect the wide variety in terms of output, professional background, and career trajectories-difficult variables to classify — we have otherwise opted for a random selection of authors.

In order to gauge the reception of Syrian authors in Europe and the US as well as in the Arab world, we have counted interviews, reviews, and other published texts about the authors in French, English, German, Spanish, Italian, and Arabic. The corpus is limited to texts that were listed in Internet searches using the Google search engine between 2014 and 2016. Compared to a systematic search of a limited number of publications, this search yields a greater range of publications and gives a broader picture of the authors' reception. The data should not be taken to represent a full record of publications about an author's work. However, they will contain the vast majority of articles visible to internet users between 2014 and 2016. Consequently, few articles will date from before 2000 and more recent articles are bound to be overrepresented. Nonetheless, I believe that these numbers are suitable to give us a broad overview of the relative importance of these intermediaries for Syrian authors at different stages of their career.

\section{Social Media}

With the conflict in Syria, social media have gained new importance for many Syrians abroad, including authors of fiction and poetry. The social networking site Facebook, in particular, has served as a publication platform for many authors. In some instances, Facebook posts have been made into books published in translation: Aboud Saeed's ('Abūd Sa īd) Der klügste Mensch im Facebook (2013) is a case in point. The use of social media in furthering a literary career certainly existed before 2011, but, as can be seen with the example of Saeed, Syrian authors find themselves in a situation where the potential impact of social media use is unprecedented. Saeed, who had not appeared as an author of fiction or poetry previously, became a published author translated into several European languages (among them German, Portuguese, and Swedish) - a distinction hitherto reserved to a few highly consecrated figures of the Syrian literary field-in no more than a couple of years. Figure 3 shows that posting in social media is widespread among Syrian writers. Even among those over age 65, who might be suspected to be less versed in the use of these new media, 30\% wrote at least one post a week between May 2014 and May 2016.

Apart from this finding, it is maybe unsurprising that the percentage of writers making frequent use of social media for publication is highest between the two lower age groups. This, however, shows the transformative potential of social media platforms for the field: the lower age groups typically contain the less consecrated writers. Due to their presence on social media, they are more likely 


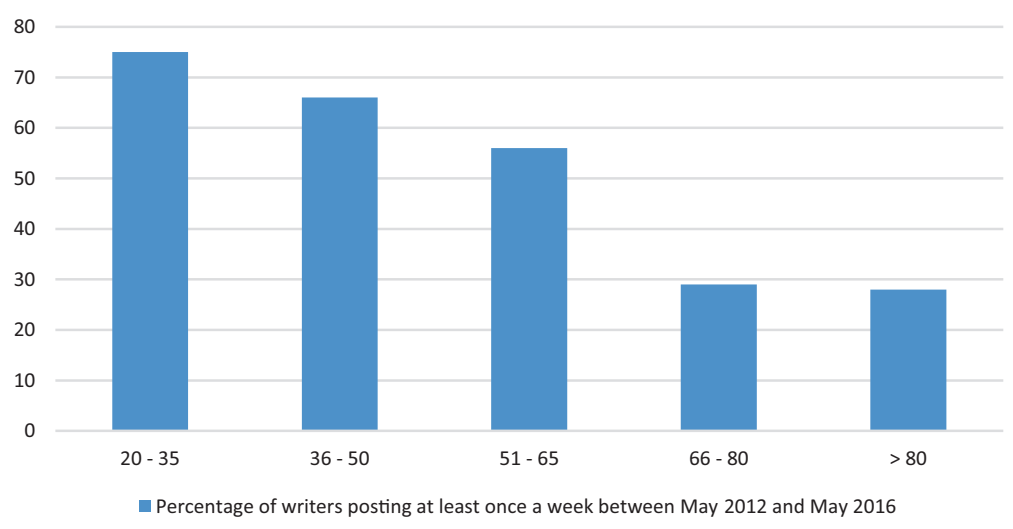

Fig. 3 Social Media Posts

to profit from the symbolic capital that can be accumulated through these sites and are thus able to circumvent the established gatekeepers of the literary space, which becomes a challenge to the established hierarchies of the field.

\section{US/European Media}

For a long time now, the institutions of consecration of the Euro-American literary fields have played an important role for Arab, and by consequence Syrian authors. Translation into foreign languages, hitherto the prerogative of literary figures well recognized in the Arab literary space, has always been a mark of distinction. However, the translation and publication of an entire literary work is not necessarily a prerequisite for an author to be recognized by Euro-American media. In the case of Syrian authors after 2011, the publication of shorter translated texts in anthologies, literary magazines, or as part of the activities of public diplomacy organizations, such as British Council or Germany's Goethe Institut, made authors visible in the international media. Thus an extract of Samar Yazbek's Diaries of a Revolution, which appeared in Arabic in 2012, had already circulated in the European press in the second half of 2011 (Yazbek, August 3, 2011a; August 10, 2011b; December 3, 2011c), laying the groundwork for Yazbek's wider recognition as an important literary voice in the context of the conflict in Syria.

When we consider the average number of contributions per single author that we found in European and US media, it is interesting to note that the age group that enjoys the greatest recognition is not the age group that typically comprises 


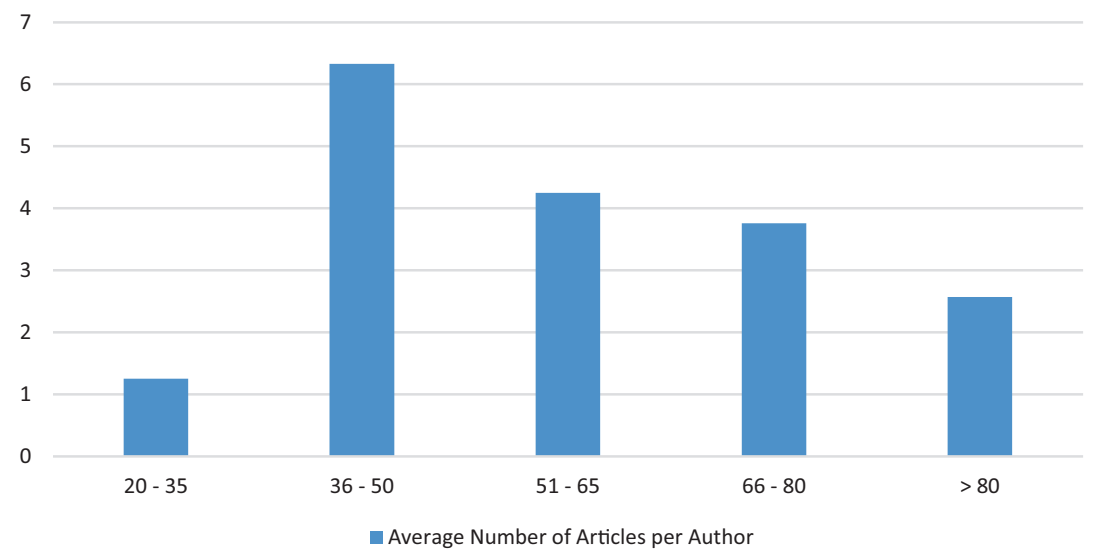

Fig. 4 Articles in US/European Media

the field's highly recognized — and translated-figures such as Faraj Bairaqdar, Nabil Sulaiman (Nabīl Sulaymān), Nihad Siris, and Zakariya Tamir (Zakarīyā Tāmir) (see Fig. 4).

This certainly has to do with the fact that a number of these-Bairaqdar and Tamir among them-have long lived in exile in Europe. The interest of European media mainly lay with the illustration of current events in Syria. Again, this prioritization of the symbolic capital of "being there," or at least "having been there recently," is bound to lead to a challenge, and possibly a transformation, of the hierarchies in the field. The fact that Euro-American media have solicited authors increases their visibility for publishers, but also for cultural journalists. For the literary avant-gardes, serving as an expert on Syria can appear to be an inroad into European cultural spaces, or at least certain dominated segments thereof, and a shortcut to the position of the translated author and the associated symbolic capital which can be used in the competition with their peers.

\section{Arab Media}

Arab media, especially the literary supplements of major newspapers, comprise some of the most important gatekeepers and institutions of consecration when it comes to Arabic literature ${ }^{8}$. Therefore, we would expect that highly recognized 


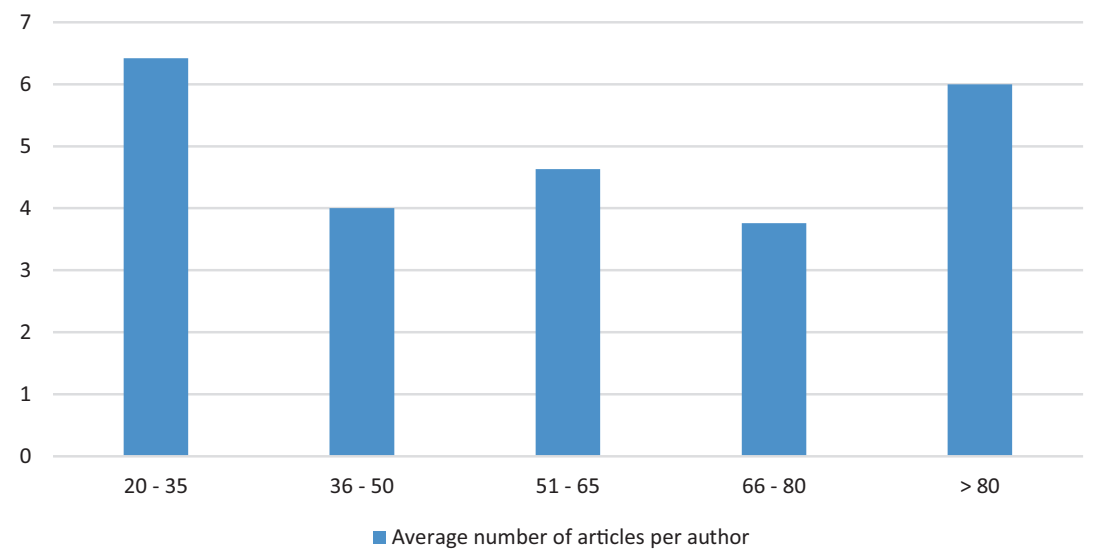

Fig. 5 Articles in Arab Media

authors, who are frequently those in the older age groups, would have the highest numbers of articles to their name (Fig. 5).

Indeed, the group of writers older than 80 scores relatively high. What needs further explanation, however, is the high scores for writers between the ages of 20 to 35 .

To a certain extent, this could be explained with the small sample: publications about the authors are rather unevenly distributed, as the sample contains well-known as well as very little-known authors. Of the seven authors in this young age group, two, Muștafā Tāj al-Dīn al-Mūsā and 'Abdallāh Maksūr, who are fairly advanced in their careers and have already published several novels, account for almost $40 \%$ of the publications between them. In addition, both have published widely in Arab media and are likely to possess the professional networks to bring their work to the attention of potential reviewers. Both had recently published works related to the conflict in Syria and one of them received an award for his short stories in 2015. While there are many reasons to suspect that the overall average for authors in this age group is lower, it would seem that the attention of journalists and reviewers in the Arab media is more evenly distributed, and therefore less disruptive to the established hierarchies than that of their Euro-American counterparts. 


\section{Conclusion}

Summing up, it appears that the practices of translation and the greater importance of social media and Euro-American media for Syrian authors' literary careers favor emerging authors by offering access to new resources for symbolic capital. How the rise of this generation of authors will play out in the competition with the consecrated writers of the older generations seems far from clear. For the time being, we can observe the formation of an international segment of the Syrian field, which is in the process of establishing its own hierarchies. This will certainly change the space in which all Syrian writers, including those in the national segment of the field move. However, considering the field as a whole, it is too early to speak of a "turning point." Clearly, challenges to the existing structure and hierarchies are evident, as are the innovations in form and content pointed out by the scholars of Syrian art and literature referenced above. The revolution and the war play a role in perpetuating and intensifying processes of change that have been evident before this political crisis, and which, in due course, might lead to the "deep transformations of the symbolic relations of force" (Bourdieu 1996, p. 126) which could be said to define a "turning point" in the Bourdieusian conceptual framework. If transformation happens, it will not only, and not even mainly, be because of the war, but because of the complex interrelations of the field of politics with internal processes at work in the space of literary production which go back to before 2011 .

The cautious wording of the analyses above reflects the limits of the quantitative approach pursued in this paper. The fact that there are no official publication records in the countries of the Arab world complicates the compilation of data, as does the often incomplete bibliographic information in older published books and the fact that newspaper archives are only partially digitized and searchable. This list of problems could easily be extended. Still, it is worth further developing methods for the quantitative study of Arabic literature as a contribution to an otherwise largely anecdotal social history of literary production. Given the general lack of sources for the study of social networks of literary production in modern Arabic literature - such as edited collections of writers' correspondence, for instance - and the dearth of research on the subject in the past, publication data is one of the very few opportunities we have for investigating networks of literary production in the past, other than interviews and notoriously unreliable human memories.

At the very least, as I showed in this chapter, counting articles, books and Facebook posts can help us form hypotheses about structural changes that can be 
corroborated by further qualitative and archival research. In the end, it is certainly worthwhile to extend the use of quantitative methods to the analysis of content and form, following the example of digital humanities research in German or English literary studies - not in an attempt to replace the "traditional" analyses of artworks, but in order to seize the opportunity to ask new and different questions.

\section{Endnotes}

1. On the functions of political crises in the Arab cultural fields, see Lang 2019b.

2. The database is part of the activities of the research group "Figures of Thought I Turning Points. Cultural Practices and Social Change in the Arab World" headed by Prof. Friederike Pannewick and funded by the German Research Foundation (DFG).

3. Dubois's work focusing on Syrian playwrights (Dubois 2018, 2019) is among these. Another example, albeit pertaining to a different time period and country, is Tristan Leperlier's work on publishing in Algeria during the Black Decade (Leperlier 2018).

4. This was the case for university graduates quite generally. In $2003,58 \%$ of graduates were employed in the public sector (Dickinson 2016).

5. On the Dahnon website, for instance, we can find pieces by Rosa Yassin Hassan, Dima Wannous, Fadi Azzām and Muștafā Tāj al-Dīn al-Mūsā, all of whom are established writers in the field. Rasha Abbas is an example for an author for whom the publication of short stories on such platforms played an important role for the entry to the field. See Lang 2019a.

6. See Al Junaidy on the Syrian presence in the Gulf countries (2018).

7. See, for instance, Edward Said's classic essay on "Embargoed Literature" (Said, September 17, 1990) and Jacquemond 2008.

8. See Jacquemond 2003, p. 102, for the case of Egypt, and Lang 2016, p. $25 \mathrm{ff}$., for the case of Lebanon.

\section{References}

Al Junaidy, Maher. 2018. Gulf countries as a destination for Syrian financial capital: The case of the United Arab Emirates. Arab reform initiative. https://archives.arab-reform. net/en/node/1423. Accessed: 25 May 2020.

Bourdieu, Pierre. 1996. The rules of art: Genesis and structure of the literary field. Stanford: Stanford University Press.

Chiti, Elena. 2016. Ecrire l'inattendu: Les “printemps arabes" entre fictions et histoire. Louvain-la-Neuve: Academia-L'Harmattan. 
Cooke, Miriam. 2016. Dancing in damascus: Creativity, resilience, and the syrian revolution. New York: Routledge.

Dickinson, Kay. 2016. Arab cinema travels: Transnational Syria, Palestine, Dubai and Beyond cultural histories of cinema. London: Palgrave Macmillan.

Dubois, S. 2018. Négocier son identité artistique dans l'exil. Les recompositions d'un paysage créatif syrien à Berlin. Migration/Sociétés 4: 45-57.

Dubois, S. 2019. A field in exile: The Syrian theatre scene in movement. In Culture and crisis in the Arab world: Production and practice in conflict, ed. R. Jacquemond and F. Lang, 169-192. London: I.B. Tauris.

Hasan, Rūzā Yāsīn. 2000. Samā' mulawwatha bi-l-daw': Qisas. Beirut: Dār al-Kunūz al-Adabīya.

Jacquemond, Richard. 2003. Entre scribes et écrivains. Aix-Marseille: Arles.

Jacquemond, Richard. 2008. Les flux de traduction entre le francais et l'arabe depuis les années 1980. In Translatio: Le marché de la traduction en France a l'heure de la mondialisation, ed. Gisele Sapiro, 347-370. Paris: CNRS Éditions.

Kahf, M. 2001. The silences of contemporary Syrian literature. World Literature Today 75 (2): 224-236.

Khalīfa, Kh.ālid. 2000. Dafātir al-qurbāṭ. Damascus: Ward.

Lang, F. 2016. The Lebanese post-civil war novel. Memory, Trauma, and Capital. London: Palgrave MacMillian.

Lang, F. 2019. Bourdieu, Latour and Rasha Abbas: The uses of ANT for studying the field(s) of cultural production in the Middle East and North Africa. Cultural Sociology 13 (4): 428-443.

Lang, F. 2019. Beauty, goodness, and bombs: The role of political crisis in structuring the MENA field of cultural production. In Culture and crisis in the Arab world: Production and practice in conflict, ed. R. Jacquemond and F. Lang, 13-38. London: I.B. Tauris.

Leperlier, Tristan. 2018. Algérie, les écrivains de la décennie noire. Paris: CNRS Éditions.

Leperlier, Tristan. 2019. The Algerian Literary Field in the 'Black Decade': A Reinforced Polarization. In Culture and crisis in the Arab World: Production and practice in conflict, ed. R. Jacquemond and F. Lang, 129-144. London: I.B. Tauris.

Saeed, Aboud. 2013. Der klügste Mensch im Facebook: Statusmeldungen aus Syrien. Transl. Sandra Hetzl. 2. Aufl. Berlin: Mikrotext.

Said, Edward. 1990. Embargoed literature. The Nation 251 (08): 278-280

Wedeen, L. 2013. Ideology and humor in dark times: Notes from Syria. Critical Inquiry 39 (4): 841-873.

Yazbek, Samar. 1999. Bāqat harīf: Qișaș. Damascus: Dār al-Jundī.

Yazbek, Samar. 2011a. A testimony from Syria. The guardian. https://www.theguardian. com/books/2011/aug/03/author-author-samar-yazbek-syria. Accessed: 29 July 2014.

Yazbek, Samar. 2011b. 'Je n'ai jamais entendu de semblables cris de douleur'. Libération. https://www.liberation.fr/monde/2011/08/10/je-n-ai-jamais-entendu-de-semblables-crisde-douleur_754153. Accessed: 29 July 2014.

Yazbek, Samar. 2011c. Ganz unten, in der Dunkelheit. Süddeutsche Zeitung: Der große Jahresrückblick.

Ziter, Edward. 2015. Political performance in Syria: From the Six-day war to the Syrian uprising. Basingstoke: Palgrave Macmillan. 
Felix Lang holds a PhD in Arabic Literature and Culture from Philipps-Universität Marburg (Germany). He is a postdoctoral research fellow in the department of Arabic Literature and Culture and coordinator of the "Figures of Thought I Turning Points" research group (DFG-Leibniz), and author of The Lebanese Post-Civil War Novel: Memory, Trauma, and Capital.

Open Access This chapter is licensed under the terms of the Creative Commons Attribution 4.0 International License (http://creativecommons.org/licenses/by/4.0/), which permits use, sharing, adaptation, distribution and reproduction in any medium or format, as long as you give appropriate credit to the original author(s) and the source, provide a link to the Creative Commons license and indicate if changes were made.

The images or other third party material in this chapter are included in the chapter's Creative Commons license, unless indicated otherwise in a credit line to the material. If material is not included in the chapter's Creative Commons license and your intended use is not permitted by statutory regulation or exceeds the permitted use, you will need to obtain permission directly from the copyright holder.

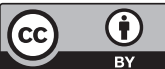

